\title{
Effect of Chloride and Sulphate Dominated Salinity on Growth and Chlorophyll Content of Senna (Cassia angustifilia Vahl.)
}

\author{
Suman Bala* and U.K. Varshney \\ Department of Botany and Plant Physiology, CCS Haryana Agricultural University, \\ Hisar-125004, Haryana, India \\ *Corresponding author
}

\section{A B S T R A C T}

The present study was aimed at evaluating chloride and sulphate dominated salinity stress tolerance status of the Senna (Cassia angustifolia Vahl.) at vegetative, flowering and pod maturity stage, a pot factorial experiment based on randomized complete design with three replicates was conducted in screen house. Four varying EC levels viz. control (without

\section{Keywords}

Salinity stress,

Growth,

Chlorophyll,

Sulphate, Chloride

and senna

Article Info

Accepted:

24 February 2018

Available Online:

10 March 2018

salt), 4,8 and $12 \mathrm{dSm}^{-1}$ of each salinity types along with nutrients supplemented in sand filled polythene bags. The present study revealed that various growth attributes such as plant height, number of leaves per plant, leaf dry weight per plant and stem and branches dry weight per plant progressively reduced with the successive increase of EC levels in the growing medium at different stages. Although the two salinity types did not differ significantly in their response on plant height, number of leaves per plant and leaf dry weight per plant at the vegetative stage but their differential effect became more pronounced at the flowering and pod maturity stages. Significant differential response of the two salinity types on stem and branches dry weight per plant was recorded only at the pod maturity stage. Significant decline in chlorophyll ' $a$ ', chlorophyll ' $b$ ' and total chlorophyll content of Senna with concomitant increase of EC level at the vegetative stage. More conspicuous reduction in growth attributes and contents of above pigments was observed under sulphate dominated salinity as compared to chloride dominated salinity. Senna appeared to be highly salt tolerant medicinal herb as its plant survived and reproduced at highest salinity level $\left(12 \mathrm{dSm}^{-1}\right)$.

\section{Introduction}

Cassia angustifolia Vahl. is commonly known as Indian senna in English, Senai in Hindi and sonamukhi in Rajasthani and it is an important medicinal plant species belonging to the family caesalpiniaceae. It is a native to Sudan and Arabia and cultivated mainly in India and Pakistan. It is now also grown on a small scale in Andhra Pradesh, Karantaka, Kerala,
Madhya Pradesh, Maharasthra, Rajasthan and Haryana. The total export of senna leaves from India is of about Rs. 20 million. The leaves and pods of this species produce crude drug senna. $C$. angustifolia grows well in warm arid regions. It can be grown in a wide range of soil. Sandy loam soil of $\mathrm{pH}$ range 6 to 8.5 is suitable for its cultivation. For economic yield as rainfed crop, it requires on average rainfall of 25 to $40 \mathrm{~cm}$. The leaves and pods of 
Cassia angustifolia are cathartic, contains sennosides A, B, C, D, rhein and aloe-emodin. It is useful in loss of apetite, hepatomegaly, spleenomegaly, indigestion, malaria, skin diseases, jaundice and anaemia. It is also used as expectorant, wound dresser, carminative and laxative.

Soil salinity is one of the major abiotic stresses which restricts the distribution and productivity of crops. No climatic zone in the world is free from salinization although the general perception is focused on arid and semi-arid region.

The total global area of salt affected soils including saline and sodic soils is $831 \mathrm{~m}$ ha (Martinez-Beltran and Manzur, 2005), mainly restricted to arid and semi-arid regions, where land degradation, water shortage and population growth are a major concern (Geissler et al., 2010). Agricultural production in future will increasingly rely on our ability to grow plants on salt affected and marginal lands using saline water (Roezma and Flowers, 2008). In India about 6744968 hectares of land is affected with salinity, whereas, it accounts for 232556 hectares in state of Haryana (CSSRI, ICAR, Govt. of India, 2012). The excessive presence of these salts in the soils adversely affects several plant processes that in turn affect crop yields. Osmotic adjustment, i.e. reduction of osmotic potential due to net solute accumulation, is an important mechanism of salt tolerance in plants (Sairam and Tyagi, 2004). The reduction in osmotic potential in salt-stressed plants may stem from accumulation of inorganic ions $\left(\mathrm{Na}^{+}, \mathrm{Cl}^{-}, \mathrm{Ca}^{2+}\right.$ and $\mathrm{K}^{+}$and compatible solutes (soluble carbohydrates, amino acids, proline) and soluble sugars (Ahmad et al., 2006), allow the plant to overcome such failure and to re-establish a water potential gradient which gives it the possibility to absorb water and restore plant turgor (Xiong and Zhu, 2002).
Amelioration and utilization of these saline soils have been the focus of research for the last few decades. Technical measures like physical, chemical and mechanical have been developed to reclaim the soil, however, due to economic viability and ecological concerns, these technologies are less attractive to the farmers. With the diversification of agriculture, medicinal and aromatic plants are gaining importance in the national scenario. So, there is growing global demand for medicinal plants. With increasing demand of food for an ever increasing population in India, it is not possible to bring lands under cultivation for aromatic and medicinal plants. Salt affected lands due to high soluble salt content, excessive exchangeable $\mathrm{Na}^{+}$and poor physical properties are not suitable for raising conventional food crops. So, marginal and salt lands could be exploited for the cultivation of medicinal plants such as Senna. The present experiment was planned to study growth parameter and chlorophyll content in Senna in response to salt stress.

\section{Materials and Methods}

The experimental site was in the screen house, Department of Botany and plant physiology, Chaudhary Charan Singh Haryana Agricultural University, Hisar, Haryana. Seeds of Senna var. sona for these experiments were obtained from the Institute of Herbal Heritage (A unit of Asian Medicinal plants and Health care trust) Sonamukhi Nagar, Sangaria Fanta, Salawas Road, Jodhpur-342005 (Rajasthan), India.

\section{Culture conditions}

The plants were raised in polythene bags (18" X 15"), each containing $12 \mathrm{~kg}$ of dune sand. The sand filled polythene bags were saturated with the solution of respective salinity treatment along with the nutrient (Hogland and Arnon, 1950) before sowing. Two types 
of salinity i.e. chloride [Cl-: $\mathrm{SO}_{4}{ }^{2-}(7: 3)$; $\left.\mathrm{Na}^{+}: \mathrm{Ca}^{2+}+\mathrm{Mg}^{2+}(1: 1) ; \mathrm{Ca}^{2+}: \mathrm{Mg}^{2+}(1: 3)\right]$ and sulphate $\left(\mathrm{SO}_{4}{ }^{2-}: \mathrm{Cl}-\quad(7: 3) ; \quad \mathrm{Na}^{+}: \mathrm{Ca}^{2+}+\mathrm{Mg}^{2+}\right.$ (1:1); $\mathrm{Ca}^{2+} \mathrm{Mg}^{2+}$ (1:3) dominated salinity with three replication was given at 4 different salinity level such as 0 (control), 4, 8 and 12 $\mathrm{dSm}^{-1} .15$ seeds of Senna were sown on variously treated sand beds in polythene bags. The moisture in the bags was maintained at field capacity by adding water as and when required. After establishment of seedlings thinning was done to maintain 3 plants of uniform size in each bag.

\section{Plant height}

Height of plants $(\mathrm{cm})$ was measured from the soil surface to the terminal bud with the help of a ruler at vegetative, flowering and pod maturity stages (Table 1).

\section{Number of leaves per plant}

All the leaves of each plant were counted and recorded at vegetative, flowering and maturity stages (Table 2).

\section{Leaf dry weight per plant}

At the time of harvesting plants were taken out carefully from the bags and after washing away the sand particles adhering to the roots with copious tap water, root and shoot portions were separated with the help of scissors. Leaves were separated and dried in labelled paper envelopes in an oven at $60^{\circ} \mathrm{C}$ for $48 \mathrm{~h}$ and then their dry weights $(\mathrm{g})$ were determined after bringing them to room temperature with the help of an electronic balance (Table 3).

\section{Stem and branches dry weight per plant}

Shoot portions excluding leaves were dried in labelled paper envelopes in an oven at $60^{\circ} \mathrm{C}$ for $48 \mathrm{~h}$ and then their dry weights $(\mathrm{g})$ were determined after bringing them to room temperature with the help of an electronic balance (Table 4).

\section{Estimation of chlorophyll content}

The Chlorophyll pigments were estimated according to the method of Hiscox and Israeldtam (1979) using Dimethyl sulphoxide (DMSO).

\section{Procedure}

One hundred mg of fresh leaf portion was kept into a test tube containing $5 \mathrm{ml}$ of Dimethyl sulphoxide (DMSO). The test tube was then placed in an oven at $60^{\circ} \mathrm{C}$ for about $2 \mathrm{~h}$ or more (if required) to facilitate the extraction of the pigments. After $2 \mathrm{~h}$ and at attaining the room temperature, absorbance was read at 645 and $665 \mathrm{~nm}$ on a computer aided spectrophotometer (spectrophotometer - 119) running a multiple wavelengths programme. DMSO was used as blank. Calculations for different pigments were made according to Welburn (1994).

Chlorophyll 'a' $\left(\mathrm{mg} \mathrm{g}^{-1}\right)=\left(\left(12.3 \times \mathrm{A}_{665}-2.86\right.\right.$ $\left.\mathrm{A}_{645}\right) \mathrm{x} \mathrm{Vx} 1000 \mathrm{x} \mathrm{W}$

Chlorophyll 'b' $\left(\mathrm{mg} \mathrm{g}^{-1}\right)=\left(\left(19.3 \mathrm{x} \mathrm{A}_{645}-3.6\right.\right.$ $\left.\mathrm{A}_{665}\right) \mathrm{x} \mathrm{Vx} 1000$ x W

$\mathrm{V}=\mathrm{Volume}$ of DMSO $(\mathrm{ml})$

$\mathrm{W}=$ Weight of tissue $(\mathrm{g})$

Total chlorophyll content $\left(\mathrm{mg} \mathrm{g}^{-1}\right)=\mathrm{Chl}$ ' $\mathrm{a}$ ' + Chl 'b'

\section{Results and Discussion}

The growth of senna plants adversely affected at the vegetative stage, maximum flowering and pod maturity stages with the build-up of salinity in the growing medium. The various 
growth attributes such as plant height, number of leaves per plant, leaf dry weight per plant and stem and branches dry weight per plant progressively reduced with the successive increase of EC levels in the growing medium at different stages. The more reduction in plant height $(10.54 \mathrm{~cm})$, in number of leaves per plant (7.50) and in stem and branches dry weight per plant (1.378 g) observed at flowering stage and in leaf dry weight per plant $(1.027 \mathrm{~g})$ at maturity stage.

Although the two salinity types did not differ significantly in their response on plant height, number of leaves per plant and leaf dry weight per plant at the vegetative stage but their differential effect became more pronounced at the flowering and pod maturity stages. Significant differential response of the two salinity types on stem and branches dry weight per plant was recorded only at the pod maturity stage. Sulphate dominated salinity was found more depressive than chloride dominated salinity in this regard.

Heidari and Sarani, 2012 studied the effect of salinity on growth in Chamomile (Matricaria chamomilla L.) in controlled environment. Salinity treatment was $0,50,100$ and $150 \mathrm{mM}$ $\mathrm{NaCl}$ in nutrient solution. Results indicated that increasing salinity from 0 to $150 \mathrm{mM}$, decreased fresh weight of shoot $(76.3 \%)$ and increased of root fresh weight (53.8\%). Reductions in various growth attributes with the rise of salt stress were also recorded by many workers in Catharanthus roseus (Jaleel et al., 2008), Atriplex hortensis Var. (Kachout et al., 2009) and Morocco (Belaqziz et al., 2009). Greater toxicity of sulphate relative to chloride on growth has been reported by Deepika (2015) in german chamomile. Contrastingly, chloride salinity was found more detrimental to growth than sulphate salinity in chandrashura by Singh (2004), Varshney and Singh (2006). These results demonstrate that it is not only the level of salinity whose magnitude is harmful to growth and development but also the kind and nature of salt responsible for salinization are of crucial importance in affecting the plant growth and development. Stunting of plants and reduced dry matter production under saline environment are ascribed to both the availability of soil water and increased toxicity of sodium and chloride or sulphate ions (Gorham et al., 1985, Munns, 2009).

Present research findings have revealed significant decline in chlorophyll ' $a$ ', chlorophyll ' $b$ ' and total chlorophyll content of $4^{\text {th }}$ leaf (from top of the plant) of Senna with concomitant increase of EC level at the vegetative stage. More conspicuous reduction in the contents of above pigments was observed under sulphate dominated salinity as compared to chloride dominated salinity. Contrastingly, more reduction in above chlorophyll pigments observed under salt stress in isabgol (Nehru, 2003), chandrashura (Singh, 2004) and German chamomile (Deepika et al., 2015).

The decline in chl ' $a$ ' content with rise of salinity was more pronounced than chl ' $b$ '. The chl ' $\mathrm{a}$ ' has been reported to breakdown more rapidly than chl ' $b$ ' in the presence of salts indicating its more unstability. The stability of chl ' $b$ ' in salt poisoned plants must be due to the firm bond between this pigment and chloroplastic stroma. This bond may be provided by aldehyde group of pigment or by a different protein (Mercado, 1973). The reduction in leaf chlorophyll content under salt is attributes to the interference of salt ions with the de novo synthesis of proteins that constitute the structural components of chloroplast, rather than breakdown of chlorophyll (Sudhakar et al., 1991). The decrease in the content of chlorophyll was demonstrated to be associated with the increased activity of chlorophyllase under salinity (Rao et al., 1980) (Fig. 1-3). 
Table.1 Plant height $(\mathrm{cm})$ of Senna at different growth stages under varying salinity

\begin{tabular}{|c|c|c|c|c|c|c|c|c|c|}
\hline \multirow{3}{*}{$\begin{array}{l}\text { EC level } \\
\left(\mathrm{dSm}^{-1)}\right.\end{array}$} & \multirow{2}{*}{\multicolumn{2}{|c|}{$\begin{array}{l}\text { Vegetative Stage } \\
\text { Salinity type(ST) }\end{array}$}} & \multirow[t]{3}{*}{ Mean } & \multirow{2}{*}{\multicolumn{2}{|c|}{$\begin{array}{l}\text { Flowering Stage } \\
\text { Salinity type(ST) }\end{array}$}} & \multirow[t]{3}{*}{ Mean } & \multirow{2}{*}{\multicolumn{2}{|c|}{$\begin{array}{l}\text { Maturity Stage } \\
\text { Salinity type(ST) }\end{array}$}} & \multirow[t]{3}{*}{ Mean } \\
\hline & & & & & & & & & \\
\hline & $\begin{array}{l}\text { Chloride } \\
\text { dominated }\end{array}$ & $\begin{array}{c}\text { Sulphate } \\
\text { dominated }\end{array}$ & & $\begin{array}{l}\text { Chloride } \\
\text { dominated }\end{array}$ & $\begin{array}{c}\text { Sulphate } \\
\text { dominated }\end{array}$ & & $\begin{array}{l}\text { Chloride } \\
\text { dominated }\end{array}$ & $\begin{array}{l}\text { Sulphate } \\
\text { dominated }\end{array}$ & \\
\hline $0($ control & 7.08 & 7.08 & 7.08 & 24.21 & 24.21 & 24.21 & 30.23 & 30.23 & 30.23 \\
\hline 4 & 6.70 & 6.67 & 6.69 & 21.99 & 18.69 & 20.34 & 27.91 & 22.02 & 24.97 \\
\hline 8 & 5.97 & 5.60 & 5.78 & 19.17 & 16.12 & 17.65 & 25.41 & 21.20 & 23.31 \\
\hline 12 & 4.23 & 4.21 & 4.22 & 12.50 & 8.58 & 10.54 & 19.73 & 17.28 & 18.51 \\
\hline Mean & 5.99 & 5.89 & & 19.47 & 16.90 & & 25.82 & 22.68 & \\
\hline $\begin{array}{l}\text { CD at } \\
5 \%\end{array}$ & \multicolumn{3}{|c|}{$\begin{array}{c}\mathrm{ST}=\text { N.S., } \mathrm{EC}=0.28, \mathrm{ST} \times \mathrm{EC}= \\
15.21\end{array}$} & \multicolumn{3}{|c|}{$\begin{array}{c}\mathrm{ST}=1.01, \mathrm{EC}=0.18, \mathrm{ST} \times \mathrm{EC}= \\
15.21\end{array}$} & \multicolumn{3}{|c|}{$\begin{array}{l}\mathrm{ST}=0.75, \mathrm{EC}=1.07, \mathrm{ST} \times \mathrm{EC}= \\
1.5\end{array}$} \\
\hline
\end{tabular}

Table.2 Number of leaves per plant of Senna at different growth stages under varying salinity

\begin{tabular}{|c|c|c|c|c|c|c|c|c|c|}
\hline \multirow{3}{*}{$\begin{array}{l}\text { EC level } \\
\left(\mathrm{dSm}^{-1}\right)\end{array}$} & \multirow{2}{*}{\multicolumn{2}{|c|}{$\begin{array}{l}\text { Vegetative Stage } \\
\text { Salinity type(ST) }\end{array}$}} & \multirow[t]{3}{*}{ Mean } & \multirow{2}{*}{\multicolumn{2}{|c|}{$\begin{array}{l}\text { Flowering Stage } \\
\text { Salinity type(ST) }\end{array}$}} & \multirow[t]{3}{*}{ Mean } & \multirow{2}{*}{\multicolumn{2}{|c|}{$\begin{array}{l}\text { Maturity Stage } \\
\text { Salinity type(ST) }\end{array}$}} & \multirow[t]{3}{*}{ Mean } \\
\hline & & & & & & & & & \\
\hline & $\begin{array}{l}\text { Chloride } \\
\text { dominated }\end{array}$ & $\begin{array}{c}\text { Sulphate } \\
\text { dominated }\end{array}$ & & $\begin{array}{l}\text { Chloride } \\
\text { dominated }\end{array}$ & $\begin{array}{c}\text { Sulphate } \\
\text { dominated }\end{array}$ & & $\begin{array}{l}\text { Chloride } \\
\text { dominated }\end{array}$ & $\begin{array}{c}\text { Sulphate } \\
\text { dominated }\end{array}$ & \\
\hline 0(control & 8.33 & 8.33 & 8.33 & 16.52 & 16.56 & 16.56 & 22.22 & 22.22 & 22.22 \\
\hline 4 & 7.78 & 7.78 & 7.78 & 15.22 & 12.33 & 17.78 & 19.45 & 16.22 & 17.83 \\
\hline 8 & 6.11 & 5.45 & 5.78 & 13.33 & 10.55 & 11.94 & 17.11 & 14.67 & 15.89 \\
\hline 12 & 4.89 & 4.44 & 4.67 & 8.56 & 6.44 & 7.50 & 13.55 & 11.11 & 12.33 \\
\hline Mean & 6.78 & 6.50 & & 13.42 & 11.47 & & 18.08 & 16.06 & \\
\hline $\begin{array}{l}\text { CD at } \\
5 \%\end{array}$ & \multicolumn{3}{|c|}{$\begin{array}{c}\mathrm{ST}=\text { N.S., } \mathrm{EC}=0.58, \mathrm{ST} \times \mathrm{EC}= \\
\text { N.S }\end{array}$} & \multicolumn{3}{|c|}{$\begin{array}{c}\mathrm{ST}=0.59, \mathrm{EC}=0.83, \mathrm{ST} \times \mathrm{EC}= \\
1.17\end{array}$} & \multicolumn{3}{|c|}{$\begin{array}{l}\mathrm{ST}=0.52, \mathrm{EC}=0.74, \mathrm{ST} \times \mathrm{EC}= \\
1.05\end{array}$} \\
\hline
\end{tabular}

Table.3 Leaf dry weight per plant (g) of Senna at different growth stages under varying salinity

\begin{tabular}{|c|c|c|c|c|c|c|c|c|c|}
\hline \multirow{3}{*}{$\begin{array}{l}\text { EC level } \\
\left(\mathrm{dSm}^{-1}\right)\end{array}$} & \multirow{2}{*}{\multicolumn{2}{|c|}{$\begin{array}{l}\text { Vegetative Stage } \\
\text { Salinity type(ST) }\end{array}$}} & \multirow[t]{3}{*}{ Mean } & \multirow{2}{*}{\multicolumn{2}{|c|}{$\begin{array}{l}\text { Flowering Stage } \\
\text { Salinity type(ST) }\end{array}$}} & \multirow[t]{3}{*}{ Mean } & \multirow{2}{*}{\multicolumn{2}{|c|}{$\begin{array}{l}\text { Maturity Stage } \\
\text { Salinity type(ST) }\end{array}$}} & \multirow[t]{3}{*}{ Mean } \\
\hline & & & & & & & & & \\
\hline & $\begin{array}{c}\text { Chloride } \\
\text { dominated }\end{array}$ & $\begin{array}{c}\text { Sulphate } \\
\text { dominated }\end{array}$ & & $\begin{array}{l}\text { Chloride } \\
\text { dominated }\end{array}$ & $\begin{array}{c}\text { Sulphate } \\
\text { dominated }\end{array}$ & & $\begin{array}{c}\text { Chloride } \\
\text { dominated }\end{array}$ & $\begin{array}{c}\text { Sulphate } \\
\text { dominated }\end{array}$ & \\
\hline O(control & 0.158 & 0.158 & 0.158 & 1.327 & 1.327 & 1.327 & 1.615 & 1.615 & 1.615 \\
\hline 4 & 0141 & 0.140 & 0.141 & 1.262 & 1.118 & 1.190 & 1.596 & 1.451 & 1.524 \\
\hline 8 & 0.124 & 0.120 & 0.122 & 1.085 & 0.919 & 1.002 & 1.433 & 1.256 & 1.344 \\
\hline 12 & 0.098 & 0.090 & 0.094 & 0.799 & 0.701 & 0.750 & 1.089 & 0.965 & 1.027 \\
\hline Mean & 0.130 & 0.127 & & 1.118 & 1.016 & & 1.433 & 1.322 & \\
\hline $\begin{array}{c}\text { CD at } \\
5 \%\end{array}$ & \multicolumn{3}{|c|}{$\begin{array}{c}\mathrm{ST}=\text { N.S., EC }=0.009, \mathrm{ST} \times \mathrm{EC} \\
=\mathrm{N} . \mathrm{S}\end{array}$} & \multicolumn{3}{|c|}{$\begin{array}{c}\mathrm{ST}=0.049, \mathrm{EC}=0.069, \mathrm{ST} \times \mathrm{EC} \\
=\text { N.S. }\end{array}$} & \multicolumn{3}{|c|}{$\begin{array}{l}\mathrm{ST}=0.04 \mathrm{ST}=0.061, \quad \mathrm{EC}= \\
0.065, \mathrm{ST} \times \mathrm{EC}=\text { N.S. }\end{array}$} \\
\hline
\end{tabular}


Table.4 Stem and branches dry weight per plant (g) of Senna at different growth stages under varying salinity

\begin{tabular}{|c|c|c|c|c|c|c|c|c|c|}
\hline \multirow{3}{*}{$\begin{array}{l}\text { EC level } \\
\left(\mathrm{dSm}^{-1)}\right.\end{array}$} & Vegetative & tage & \multirow[t]{3}{*}{ Mean } & \multirow{2}{*}{\multicolumn{2}{|c|}{$\begin{array}{l}\text { Flowering Stage } \\
\text { Salinity type(ST) }\end{array}$}} & \multirow[t]{3}{*}{ Mean } & \multicolumn{2}{|c|}{ Maturity Stage } & \multirow[t]{3}{*}{ Mean } \\
\hline & \multicolumn{2}{|c|}{ Salinity type(ST) } & & & & & \multicolumn{2}{|c|}{ Salinity type(ST) } & \\
\hline & $\begin{array}{l}\text { Chloride } \\
\text { dominated }\end{array}$ & $\begin{array}{l}\text { Sulphate } \\
\text { dominated }\end{array}$ & & $\begin{array}{l}\text { Chloride } \\
\text { dominated }\end{array}$ & $\begin{array}{l}\text { Sulphate } \\
\text { dominated }\end{array}$ & & $\begin{array}{l}\text { Chloride } \\
\text { dominated }\end{array}$ & $\begin{array}{l}\text { Sulphate } \\
\text { dominated }\end{array}$ & \\
\hline D(control & 0.587 & 0.587 & 0.587 & 1.913 & 1.913 & 1.913 & 2.163 & 2.163 & 2.163 \\
\hline 4 & 0.584 & 0.557 & 0.571 & 1.780 & 1.663 & 1.722 & 2.110 & 1.950 & 2.030 \\
\hline 8 & 0.484 & 0.477 & 0.481 & 1.563 & 1.470 & 1.517 & 2.010 & 1.893 & 1.952 \\
\hline 12 & 0.390 & 0.315 & 0.353 & 1.423 & 1.333 & 1.378 & 1.820 & 1.717 & 1.768 \\
\hline Mean & 0.511 & 0.484 & & 1.670 & 1.595 & & 2.026 & 1.931 & \\
\hline CD at $5 \%$ & \multicolumn{3}{|c|}{$\begin{array}{l}\mathrm{ST}=0.026, \quad \mathrm{EC}=0.037, \\
\mathrm{ST} \times \mathrm{EC}=\mathrm{N} . \mathrm{S}\end{array}$} & \multicolumn{3}{|c|}{$\begin{array}{l}\text { ST }=0.049, \quad E C=0.070, \\
\text { ST } \times E C=\text { N.S. }\end{array}$} & \multicolumn{3}{|c|}{$\begin{array}{l}\mathrm{ST}=0.067, \mathrm{EC}=0.095, \mathrm{ST} \times \mathrm{EC}= \\
\text { N.S. }\end{array}$} \\
\hline
\end{tabular}

Fig.1 Chlorophyll 'a' ( $\mathrm{mg} \mathrm{g}^{-1}$ fresh weight) content of leaves of senna at vegetative stage under varying salinity

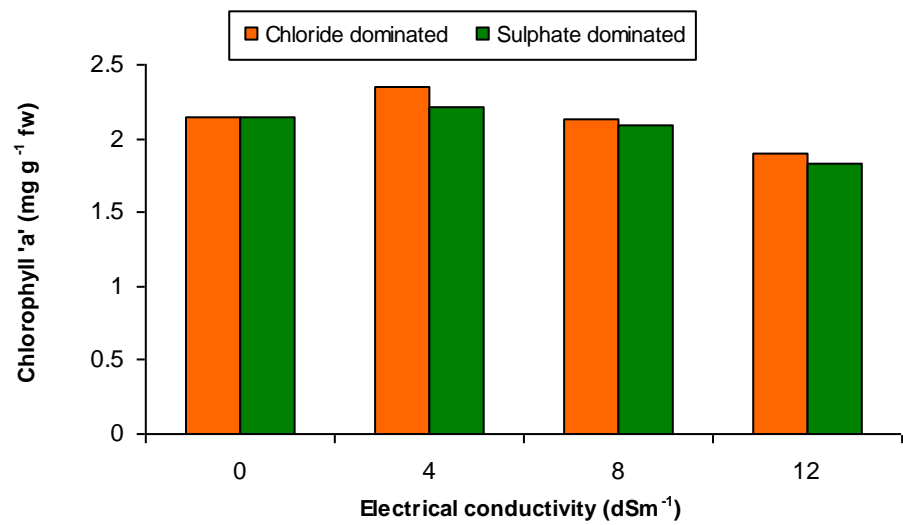

$\mathrm{CD}$ at $5 \%, \mathrm{ST}=0.014 \mathrm{EC}=0.020 \mathrm{ST} \times \mathrm{EC}=0.028$

Fig.2 Chlorophyll 'b' ( $\mathrm{mg} \mathrm{g}^{-1}$ fresh weight) content of leaves of senna at vegetative stage under varying salinity

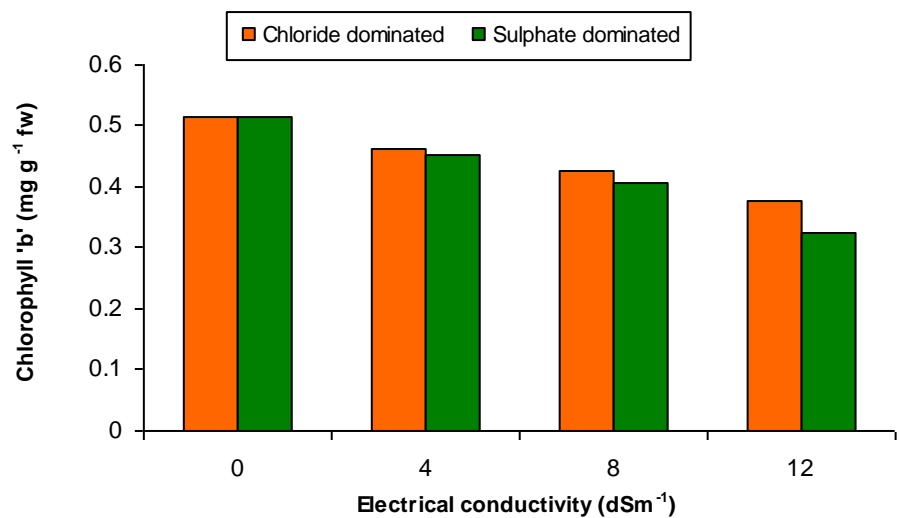

$\mathrm{CD}$ at $5 \%, \mathrm{ST}=0.006 \mathrm{EC}=0.008 \mathrm{ST} \times \mathrm{EC}=0.012$ 
Fig.3 Total chlorophyll ( $\mathrm{mg} \mathrm{g}^{-1}$ fresh weight) content of leaves of senna at vegetative stage under varying salinity

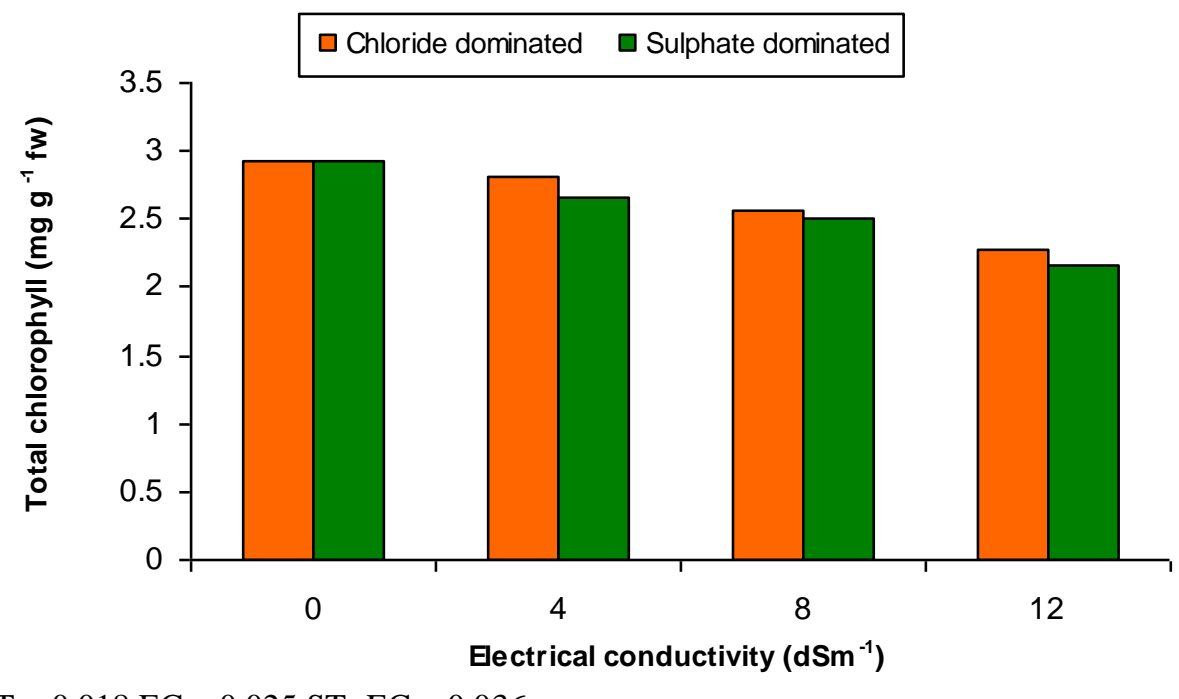

$\mathrm{CD}$ at $5 \%, \mathrm{ST}=0.018 \mathrm{EC}=0.025 \mathrm{ST} \times \mathrm{EC}=0.036$

Reduction of chlorophyll pigments under salt stress were also reported in sorghum cultivars by Azooz et al., (2004), senna by Arshi et al., (2004), Cantharanthus roseus by Elfeky et al., (2007) and Jaleel et al., (2008), German chamomile by Deepika et al., (2015), tomato by Tantawy et al., (2009) and Atriplex hortensis var. by Kachout et al., (2009) which support the present findings.

Survival of plants and more than 50\% yield of economically important parts i.e. leaves dry weight per plant upto $12 \mathrm{dSm}^{-1}$ EC level demonstrates that Senna can be grown successfully in both chloride or sulphate dominated lands upto salinity of $12 \mathrm{dSm}^{-1} \mathrm{EC}$ level.

\section{Acknowledgements}

The author thankful to Dr. U. K. Varshney, Senior Botanist-cum-Superintendent, Botanical Garden, Department of Botany and Plant Physiology, CCS HAU, Hisar for his persistent and valuable scientific guidance and close supervision throughout the tenure of this study. Author also thankful to Dr. H. R.
Dhingra, Head and Professor of Department of Botany and Plant Physiology, College of Basic Sciences and Humanities, CCS Haryana Agricultural University, Hisar for providing all the laboratory facilities to complete this work.

\section{References}

Ahmad, M.S.A., Ali Q., Bashir R., Javed F. and Khadija Alvi A., 2006. Time course changes in ionic composition and total soluble carbohydrates in two barley cultivars at seedling stage under salt stress. Pak. J. Bot. 38(5), 1457-1466

Arshi, a., Abdin, M. Z. and Iqbal, M.2004. Changes in biochemical status and growth performance of senna (Cassia angustifolia vahl.) growth under salt stress. Phytomorphology. 54, 109-124.

Azooz, M.M., Shaddad, M.A. and AbdelLatef, A.A. 2004. The accumulation and compartmentation of proline in relation to salt tolerance of three sorghum cultivars. Indian J. Plant Physiol. 9, 1-8.

Belaqziz, R., Romane, A. and Abbad A. 2009. Salt stress effects on germination, 
growth and essential oil content of endemic thymes species in morocco (Thymus maroccanus Ball.). J. of Applied scienes Research. 5, 858-863.

CSSRI, ICAR, Govt. of India Report.2012. Extent and distribution of salt affected soils in India.

Deepika, Varshney, U. K., Sangwan, P., Manogya, Singh, S. and Preeti. 2015. Influence of salinity on morphophysiological characters of German chamomile (Matricaria chamomilla L.). World J. of pharmacy and Pharmaceutical sciences. 4, 762775.

Elfeky, S., S., Osman, M. E. H., Hamada, S., M. and Hasan, A. M. 2007. Effect of salinity and drought on growth criteria and biochemical analysis of Catharanthus roseus shoot. International J. of Botany. 3, 202-207.

Geissler, N., S. Hussin and H.W. Koyro. 2010. Elevated atmospheric CO2 concentration enhances salinity tolerance in Aster tripolium. L. Planta. 231, 583-594.

Gorham, J., Wyn Jones, R. G. and McDonneil, F. 1985. Some mechanism of salt tolerance in crop plants. Plant Soil. 85, 15-40.

Heidari, M. and Sarani, S. 2012. Growth, biochemical components and ion contents of chamomile (Matricaria chamomilla L.) under salinity stress and iron deficiency. Journal of Saudi Society of Agricultural Sciences. 11(1), $37-42$.

Hiscox, J. D. and Israeldtam, G.F. 1979. A method for the extraction of chlorophyll from leaf tissue without maceration. Can. J. Bot. 57, 1332-1334.

Hoagland, D. R. and Arnon, D. I. 1950. Water culture method for growing plants without soil. Univ. Calif. Agric. Stat. Circular. 347, 1-39.
Jaleel, C. A., Sankar, B., Sridharan, R. and Panneerselvam, R. 2008. Soil salinity alters growth, chlorophyll content and secondary metabolites accumulation in Catharanthus roseus. Turk J Bot. 32, 79-83.

Kachout, S. S., Mansoura, A. B., Jaffel, K., Leclerc, J. C., Rejeb, M. N. and Ouerghi, Z. 2009. The effect of salinity on the growth of the halophyte Atriplex hortensis (Chenopodiaceae). Applied Ecology and Environmental research. 7, 319-332.

Martinez-Beltran, J. and Manzur, C. L. 2005. Overview of salinity problems in the world and FAO strategies to address to the problem. In: Proceedings of the international salinity forum. Riverside, California. pp. 311-313.

Mercado, M. 1973. Structure and function of plant cells in saline habitats. In: John Wiley and Sons (eds.). New York. Israel Program for Scientific Translation Ltd. Jerusalem - London.

Munns, R., Hare, R. A., James, R. A. and Rebetzke, G. J. 2009. Genetic variation for improving the salt tolerance of durum wheat. Functional plant Biol. 36, 442.

Nehru, V. 2003. Physiological responses of Isabgol (Plantago ovata Forsk.) genotypes to salt stress. M.Sc. Thesis, CCS Haryana Agricultural University, Hisar, India.

Rao, G. G., Mallikarjuna, K., Rao, P.G. and Rao, g. R. 1980. Physiological changes in early seedling growth of green gram (Phaseolus radiate L.) under $\mathrm{NaCl}$ salinity. Indian J. Exp. Biol. 18, 320322.

Rozema, J. and Flowers, T. 2008. Crops for a salinized world. Science. 322, 14781480.

Sairam R. K., Tyagi A. 2004. Physiology and molecular biology of salinity stress 
tolerance in plants. Curr. Sci., 86, 407421.

Singh, H. 2004. Physiological responses of chandrashura (Lepidium sativum L.) to salt stress. M.Sc. Thesis, CCS Haryana Agricultural University, Hisar, India.

Sudhakar, C., Reddy, P. S. and Veeanjaneyulu, K. 1991. Changes in respiration, its allied enzymes, pigment composition, chlorophylase and hill reaction activity of horse gram seedling under salt stress. Indian J. Plant Physiol. 34, 171-177.

Tantawy, A. S., Mawgoud, A. M. R. A., Nemr, M. A. E. and Chamoun, Y. G.
2009. Alleviation of salinity effects on tomato plants by application of amino acids and growth regulators. European J. of Scientific research. 30, 484-494.

Varshney, U. K. and Singh, H. 2006. Effect of salt stress on growth and yield of the medicinal plant chandrashura (Lepidium sativum L.). All Ind. Sem. On Adv. In Botanical, Biotechnology and Microbiology Res. In Ind. During last decade (1996-2006), Bikaner, P.83.

Xiong L. And Zhu J.-K., 2002. Molecular and genetic aspects of plant responses to osmotic stress. Plant, Cell, Environ. 25, 131-139.

\section{How to cite this article:}

Suman Bala and Varshney, U.K. 2018. Effect of Chloride and Sulphate Dominated Salinity on Growth and Chlorophyll Content of Senna (Cassia angustifilia Vahl.). Int.J.Curr.Microbiol.App.Sci. 7(03): 2797-2805. doi: https://doi.org/10.20546/ijcmas.2018.703.322 